\title{
Cytokine Release Syndrome: An Overview on its Features and Management
}

\author{
Shailza Shreshtha ${ }^{1}$, Pradeep Kumar ${ }^{1}$, Preeti Sharma ${ }^{1 *}$ and Rachna Sharma ${ }^{2}$ \\ ${ }^{1}$ Department of Biochemistry, Santosh Medical College and Hospital, Ghaziabad - 201 001, India. ${ }^{2}$ Department of \\ Biochemistry, TSM Medical College and Hospital, Lucknow - 226 003, India.
}

\begin{abstract}
Cytokine release syndrome (CRS) is a life threatening toxicity associated numerous immunotherapeutic techniques involving monoclonal antibodies, bispecific antibodies and adoptive $T$ cell therapies. It is also referred as infusion reaction that results in release of large amount cytokines (Like IL-6, IFN-r, INF) from the target cells. Cytokines when released in excessive amounts into the circulation produces systemic symptoms like nausea, shills, fever, rashes, headache, hypotension, dyspenea etc. Most of the patients present mild to moderate symptoms which can be managed easily but some patients show life threatening symptoms. Studies have shown that immunosuppressive agents like corticosteroids and tocilizumab can reverse the toxicity of CRS, however such immunosuppression may limit the immunotherapeutic efficacy. Therefore specific precautions must be considered in such patients to present exacerbation of the complication. Thus this review is based on the overview of CRS which include etiology, mechanism and management of CRS, so that immunotherapeutic benefits can be maximized with minimum risk of complication.
\end{abstract}

Keywords: Cytokine release syndrome, monoclonal antibodies, chimeric antigen receptor modified T- cells, cortiocsteroids, tocilizumab.

\footnotetext{
*Correspondence: prcdri2003@yahoo.co.in

(Received: 17 January 2019; accepted: 01 March 2019)

Citation: Shailza Shreshtha, Pradeep Kumar, Preeti Sharma and Rachna Sharma, Cytokine Release Syndrome: An Overview on its Features and Management, J Pure Appl Microbiol., 2019; 13(1):133-140 doi: 10.22207/JPAM.13.1.14

(c) The Author(s) 2019. Open Access. This article is distributed under the terms of the Creative Commons Attribution 4.0 International License which permits unrestricted use, sharing, distribution, and reproduction in any medium, provided you give appropriate credit to the original author(s) and the source, provide a link to the Creative Commons license, and indicate if changes were made.
} 


\section{INTRODUCTION}

Treatment of various disorders whether malignant or non-malignant via use of mono-clonal antibodies or adoptive therapy using modified T cells, have now evolved as an integral part in clinical practice. Though there is wide spread use, such treatment regimen can also result in serious and fatal outcomes, one of which is described as Cytokine release syndrome (CRS) 1 .

Cytokines, the chemical messengers that are protein in nature, are produced by majority of the cells in the body ${ }^{2}$. Some examples of cytokines are interleukins (ILS), tumor necrosis factor (TNF) and interferons (IFNs). Broadly cytokines may be categorized as monokines, lymphokines and chemokines. Cytokines of macrophages or monocytes origin are called monokines while cytokines that originate from lymphocytes are termed as lymphokines. Similarly the cytokines that attract immune effector cells to the targeted area by binding on to the target cells are known as chemokines ${ }^{1}$.

Cytokines perform various functions in the body. Some of them are as follows:

Aid in cell to cell communication

Involved in hematopoiesis

Regulate the functions of both innate and acquired immune system and also coordinate their responses with various organs ${ }^{2}$

Stimulate or inhibits cellular growth

Activate lymphocytes or other immune effector cells
Stimulate degradation of monoclonal antibody targeted cells

Mediates inflammatory responses ${ }^{1}$.

Cytokines exhibit regulatory functions similar to that of hormones; however they are distinct from hormones with regards to pleotropic function and redundant nature ${ }^{2}$. They are important in host defense and tissue homeostasis but abnormally high level can cause acute and chronic impairments, one of the known examples being cytokine release syndrome (CRS). CRS was unknown till 1990s when it was observed in the patients whom Muromonab CD3 (anti-mouse monoclonal antibody) was administered to treat allograft rejection ${ }^{3}$. After this several other antibodies associated with CRS were identified such as Chimeric rituximab (antiCD20), Humanised alemtuzumab (anti-CD 52) and TGN1412 (CD 28 agonist).

CRS is a cytokine associated toxicity that results from excessive immune activation. Immune activation is the basic mechanism underlying modern immunotherapies in order to attain desired clinical benefit. However, activation of immune system by immunotherapeutic agents beyond the normal results in the flooding of cytokine and adverse effects. Since immunotherapeutic techniques are becoming more trendy in the recent times, the prevalence of CRS is also increasing 5 .

Some recent reports have shown that CRS can also develop after infusion of bispecific

Table 1. Symptoms associated with CRS and sites of body affected

\begin{tabular}{|c|c|}
\hline $\begin{array}{l}\text { Organ systems } \\
\text { affected }\end{array}$ & Symptoms \\
\hline Constitutional & Fever, headache, anorexia, malaise, myalgias, rigors ${ }^{11,12}$ \\
\hline Integument & Skin rashes ${ }^{11}$ \\
\hline Blood & Cytopenias (anaemia, leucopenia, lymphopenia, thrombocytopenia), increase \\
\hline \multicolumn{2}{|c|}{ in D-dimer, hypofibrinogenemia ${ }^{10,13}$} \\
\hline Cardiovascular & $\begin{array}{l}\text { Mild: Tachycardia with feverSevere: Hypotension, decreased cardiac output, } \\
\text { arrhythmias, cardiac arrest }{ }^{14,15}\end{array}$ \\
\hline $\begin{array}{l}\text { Pulmonary } \\
\text { required in some case }\end{array}$ & $\begin{array}{l}\text { Hypxia, dyspnea, pulmonary edema, pneumonitis, mechanical ventilation } \\
\mathrm{s}^{5,16}\end{array}$ \\
\hline Gastrointestinal & Diarrhoea, abdominal pain, colitis, hyperbilirubinemia, transaminitis ${ }^{17,18}$ \\
\hline Renal & Electrolyte imbalances, azotemia, renal injury due to reduced renal perfusion ${ }^{11,15}$ \\
\hline $\begin{array}{l}\text { Nervous } \\
\text { palsy, altered gait }{ }^{8}\end{array}$ & Headache, confusion, hallucination, dysphasia, tremor, seizure, facial nerve \\
\hline Musculoskeletal & Elevated creatine kinase, myalgias, weakness ${ }^{11,15}$ \\
\hline
\end{tabular}


antibodies such as blinatumomab (used in leukemia) ${ }^{6}$, haploid mononuclear cells (used in refractory leukemia) and adoptive immunotherapies (use of genetically engineered T-cells that express chimeric antigen receptors, CART) ${ }^{7}$. Symptoms

Symptoms associated with CRS in most of the patients are mild (flu, fever and myalgias) while they may be severe in some patients. The severe inflammatory syndromes include hypotension, vascular leak, pulmonary edema, coagulopathy and multiple organ system failure. The details of symptoms and sites of body affected are shown in table 1. Recently CRS induced death has also been reported after the administration of blinatumomab ${ }^{8}$.

Time of onset of symptoms and severity of CRS depend on the drug infused, level of immune activation and burden of the disease $e^{9}$. In case of rituximab, symptoms appear within minutes to hours after administration of drug. In some cases CRS may be followed by hemophagocytic lymphohistocytosis (HLH). Study of Grupp SA et al showed that, among the patients who had undergone CD19-CART therapy, one patient was reported to have severe CRS along with $\mathrm{HLH}$. The patient was found to have mutated perforin gene that is responsible for HLH development ${ }^{10}$. This clinical finding has aroused the question whether host genetic factor influences the occurrence of CRS following immunotherapies, which need further research evidences.

\section{Mechanism of CRS development following immunotherapy} On administration of monoclonal antibodies

There are two basic mechanisms which describes development of CRS after therapy involving monoclonal antibodies (mAB). They are type 1 reaction and type 2 reaction. Type 1 reaction involves Fab region of $\mathrm{mAB}$. Fab binds with the activation receptors present on the surface of target cells thereby leading to the generation of transduction signal and flooding of cytokines. Monoclonal antibodies such as TGN412 and muronomab act via this mechanism.

In case of type 2 reaction, there is involvement of $\mathrm{Fc}$ region of $\mathrm{mAB}$. Fc receptors present on the surface of antibody opsonised target cells bind with Fc region of antibody followed by signal transduction and massive release of cytokines. Drugs like rituximab and alemtuzumab act via this mechanism. An alternate mechanism has also been postulated which states that these antibodies may activate natural killer cells and cause flooding of cytokines through ligation of CD-16 ${ }^{3}$.

T-cell engaging therapies

\section{Genetically modified T-cells or CART}

T-lymphocytes can be genetically modified to express a domain called single chain fragment variable ( $\mathrm{scFv}$ ) region. Such modified T-cells are called CART cells. The new domain scFv binds to signaling and co-stimulatory domains (CD Z8 and CD137) of T- cell receptor ${ }^{19}$. CART cell therapy can result in CRS by direct or indirect mechanisms. In case of direct mechanism, the infused modified T cells directly induces the production and release of cytokines in excessive amount. Indirectly, such infused cells first secrete cytokines in response to which other immune cells like macrophages secrete large amount of cytokines ${ }^{20}$. T cell engaging therapies cause activation immune cascade leading to HLH/MAS in both the patients predisposed with or without known mutation in gens causing $\mathrm{HLH}^{21}$.

\section{Bispecific T-cell engagers}

Bispecific T-cell engagers, also termed as BiTEs, are molecules developed mostly for cancer immunotherapy. In BiTEs there are two single chain variable fragments (scFv) connected by a flexible linker. Of two chains, one chain links with CD3 molecule and the other binds with antigen associated tumor cells. Upon ligation T- cells are stimulated and cytokines are released that ultimately leads to tumor clearance. Various BiTEs are now being developed and subjected to clinical trials to assess their efficacy and safety. Some examples are blinatumomab (MT 103), MT 110, BAY2010112 etc ${ }^{25}$.

\section{Biomarkers and diagnosis of CRS}

In CRS, large amount of cytokines are released in circulation. However several issues are still to be addressed for effective use of such cytokine measurement to diagnose and define the severity of disorders. Some important issues are:-

Need of clinical laboratory improvement amendments (CLIA) certified assays which are not readily available in most of the hospitals.

Prediction of severity of disorders on the basis of cytokine level is uncertain ${ }^{7}$ 
Profiles of different cytokines are needed to be studied rather than single.

Though number of cytokines is produced, recent immunotherapeutic practices involve inhibition of IL- 6 signaling as, it is implicated to be a central mediator of CRS related toxicities ${ }^{7}$.

Currently CRP is also being extensively studied as a laboratory marker of CRS and its severity ${ }^{7}$. However CRP is also increased in various infections, so it lacks specificity on demarking infections associated with inflammation from infectious inflammation ${ }^{27}$. It has been observed in previous studies that levels of CRP correlated with the severity of CRS. According to Davila et al., significant differences in the levels of CRP among patients with CRS can be observed within two days after infusion of immunotherapeutic drugs and the level correlated with that of IL-6 $6^{7}$. Though targeting IL- 6 is considered successful in cancer therapy, Teachey et al stated that serum IL-6 measurement after CART infusion has no benefit since there was no significant increase in IL-6 levels in their study ${ }^{28}$. However, their observation was in contrast to that of Turtle et al who showed highly elevated IL-6 levels in the patients following infusion of CART and in the patients with severe CRS associated with neurotoxicity ${ }^{29}$. Thus more studies are required to identify specific biomarkers to CRS so that it can be diagnosed and managed beforehand of its complexities.

\section{Management of CRS}

Management of CRS is somewhat challenging. Various treatment strategies have evolved as follows:

\section{Corticosteroids}

Corticosteroids are the treatment of choice in lowering the effects of CRS in the disorders that involved activated T-cells. Examples of such disorders include inflammatory processes and graft vs. host disease ${ }^{30}$. Studies have shown that corticosteroids can be used as a routine supportive care in blina-tumomab therapy. According to Porter et al, the patient who received corticosteroids after CART-19 therapy, showed a partial response. It is postulated that steroids (Corticosteroids) when administered invitro reduces the level of cytokines without influencing bispecific T-cell engager associated activation of

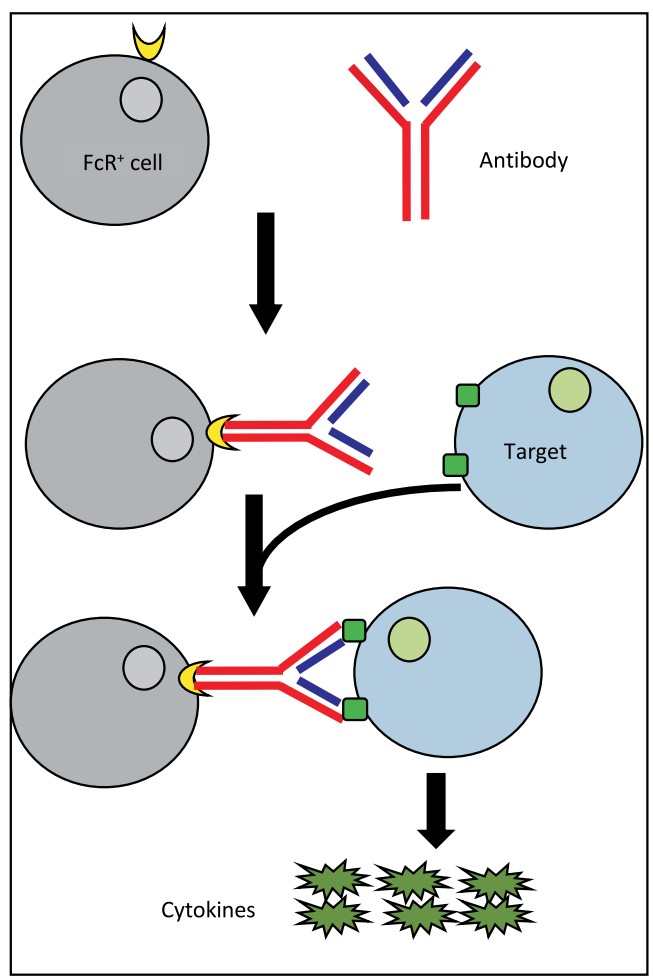

Fig. 1. Type 1 reaction

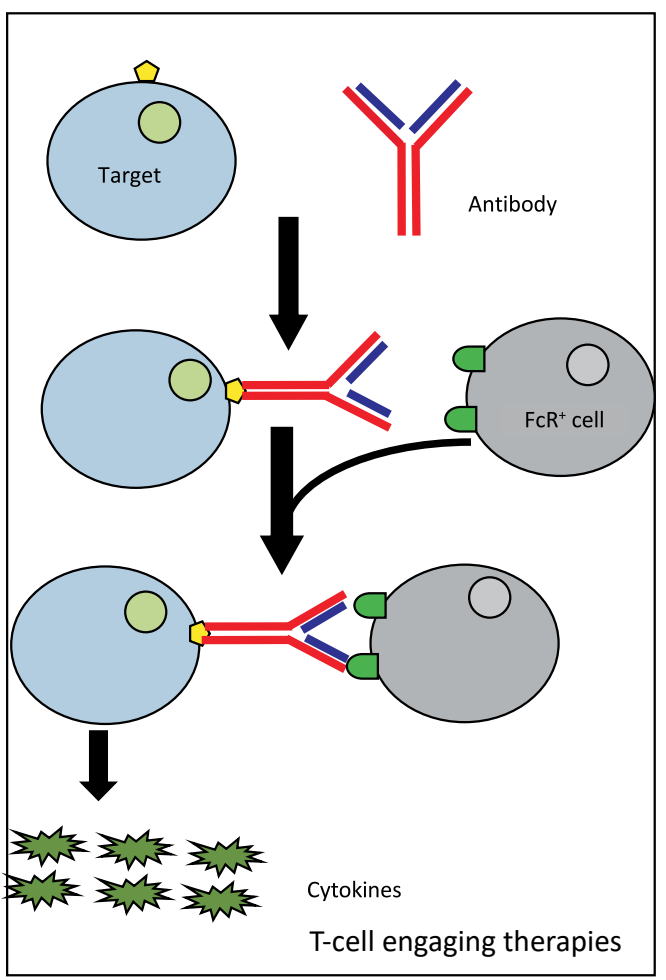

Fig. 2. Type 2 reaction 
T-cell ${ }^{31}$. However use of corticosteroids in high dose for long duration can decrease efficacy of CART- cells and limit their anti-leukemic effects ${ }^{7}$. The efficiency of corticosteroids to blunt CRS still needs to be elaborated with further researches.

\section{Targeting cytokines}

CRS can also be managed by directly targeting the elevated cytokine level. Cytokines like IL-10, IL-16 and IFN- $\tau$ are significantly increased in $\mathrm{CRS}^{32}$. These cytokines are released by monocytes or macrophages that regulate both innate and adaptive immunity ${ }^{33,34}$.

IL-10 acts as a negative regulator and thus it may not be an ideal target in CRS. Similarly, increased IFN- $\tau$ levels are required for the efficiency of T-cell therapy, thereby making it an unsuitable target. While, IL-6, though involved in inflammatory processes, it is still unclear whether it helps in proliferation of T-cell via feedback loop. However, it is hypothesized that toxicity of CRS can be reduced by suppressing IL-6 without affecting efficacy of immunotherapy. Blockade of IL- 6 by tocilizumab has shown significant withdrawal of severe CRS symptoms ${ }^{10,6}$. Tocilizumab, a IL-6 blocker, is a recombinant monoclonal antibody that prevents the binding of IL- 6 with its receptors ${ }^{35}$. It is first choice of therapy for CRS. In some patients severe CRS

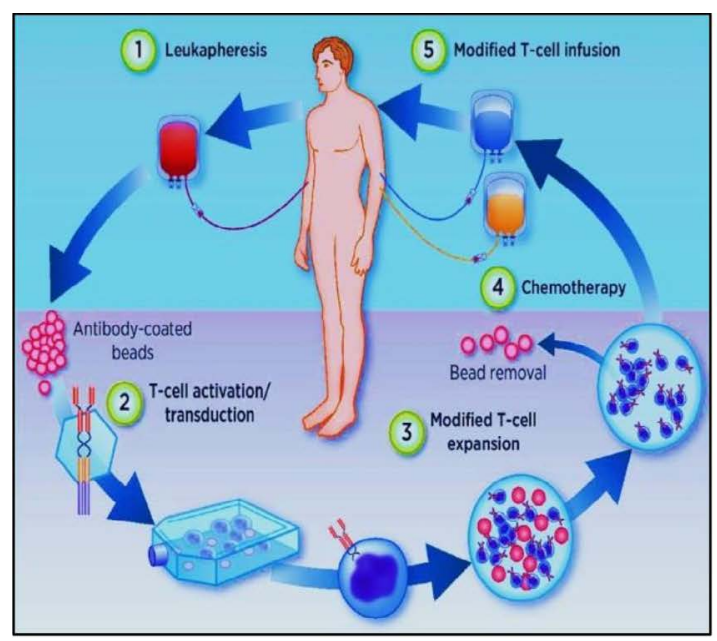

CART therapy

Fig. 3.1. Isolation of $T$ cells from blood $\rightarrow$ transfection of $T$ cells with genetically engineered viral vector $\rightarrow$ introduction of new gene to $T$ cell $\rightarrow$ insertion of engineered $\mathrm{T}$ cells back to human host ${ }^{22}$ may be associated with MAS (macrophage activation syndrome) or hemophagocytic lymphohisto cytosis (HLH). HLH is a rare immune disorder characterized by cytopenias, prolonged fever, hyperferritinemia, hypertriglyceridemia, spleenomegaly, coagulopathy, decreased efficacy of natural killer cells and elevation in cytokine level ${ }^{36}$. Tocilizumab, through used rapidly in blunting CRS manifestation, should be avoided in patients suspected with MAS22].

Other blockers of IL- 6 like situximab and IL-6 trans-signal blocker (sgp130FC) are also available commercially. They have the potential to blunt CRS but need support from further studies $^{37}$. Other cytokines which are increased in CRS include IL-ZR, MCP-1 and MIP IB. Therefore approaches for management of CRS including use of inhibitors of MCP-1 and MIBO $1 \mathrm{~B}$ are in the process of development. They are still to be used clinically while inhibitors of TNF $\gamma$, IL-1R and IL-2R have been used clinically ${ }^{38}$.

Though the numbers of therapeutic strategies are available for CRS, they may impair T-cell action and treatment efficacy. Therefore, it is suggested that further in depth researchers are needed before considering the strategy postulated to be the novel therapeutic modality and also it is recommended to make treatment decisions on

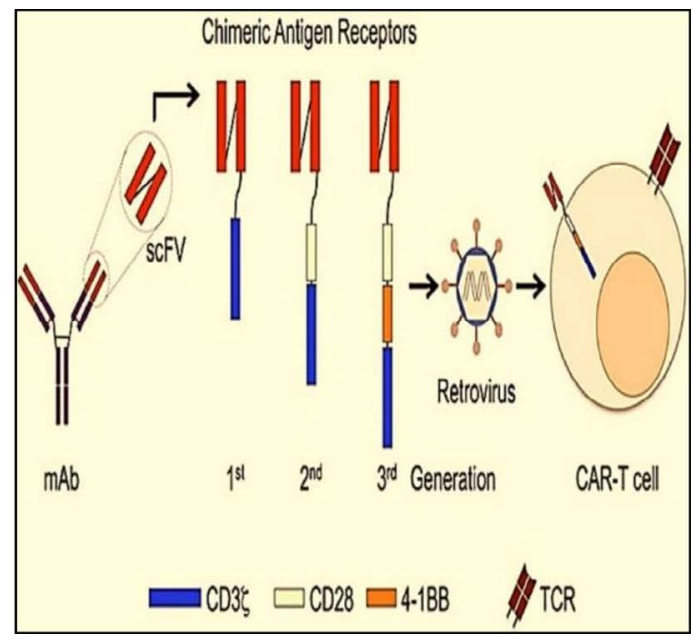

CART therapy

Fig. 3.2. CARs combine with scFVs of monoclonal antibodies. CARs are then inserted to T cells of host via viral mediated gene transfer ${ }^{23}$. 


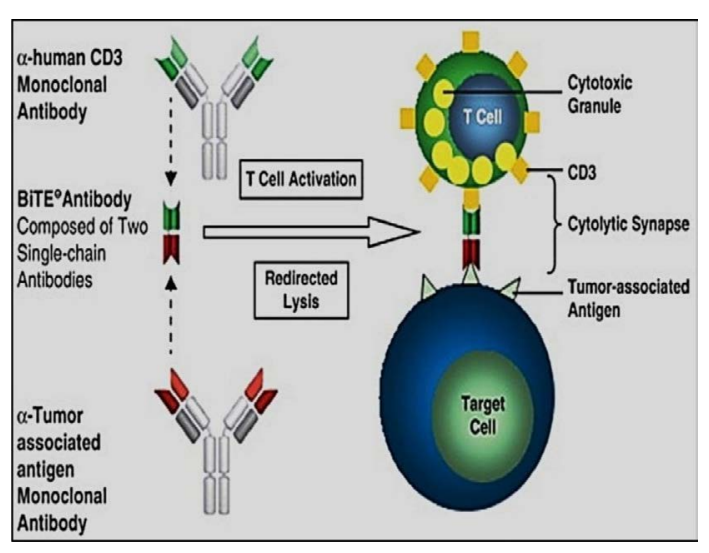

Fig. 4. Formation and action of BiTEs ${ }^{26}$

the basis of clinical parameters rather than rarely analyzing the panels of cytokine released.

Grading of CRS and treatment modality 5,40

CRS associated with immunotherapies

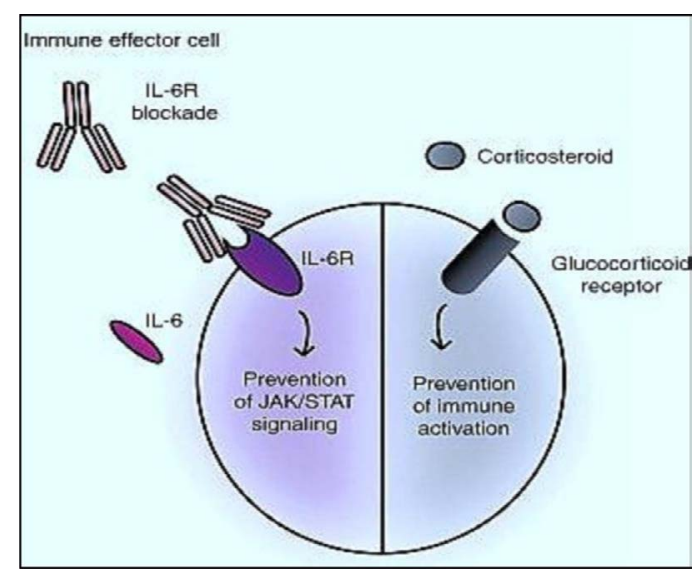

Fig. 5. Action of IL-6 blockers and corticosteroids ${ }^{38}$

involving antibodies has been categorized into 5 different grades by the National Career Institute Common Terminology for adverse events (CTCAE) as follows:

\begin{tabular}{|c|c|c|}
\hline Grade & Complications & Therapeutics \\
\hline 1 & $\begin{array}{l}\text { No associated life } \\
\text { threatening complications }\end{array}$ & Symptomatic treatment can be applied \\
\hline 2 & $\begin{array}{l}\text { Low grade hypotension, mild } \\
\text { respiratory symptoms (hypoxia), } \\
\text { grade } 2 \text { organ toxicity }\end{array}$ & $\begin{array}{l}\text { Moderate therapeutic interventions required } \\
\text { For hypotension: -fluids or vasopressors (Low Dose) } \\
\text { For hypoxia: - low flow oxygen }(<48 \%) \rightarrow \text { Monitor } \\
\text { function of heart and other organs }\end{array}$ \\
\hline 3 & $\begin{array}{l}\text { High grade hypotension, } \\
\text { hypoxia, grade } 3 \text { organ toxicity } \\
\text { like coagulopathy, renal } \\
\text { dysfunction, cardiac dysfunction } \\
\text { and grade } 4 \text { transaminitis }\end{array}$ & $\begin{array}{l}\text { Aggressive intervention is needed } \\
\text { For hypotension: - high dose or multiple } \\
\text { vasopressor drugs } \\
\text { For hypoxia: -high flow oxygen }(<40 \%) \\
\text { Assessment of cardiac and other organ } \\
\text { function } \\
\text { Use of immunosup pressants (corticosteroids, } \\
\text { tocilizumab) }\end{array}$ \\
\hline 4 & $\begin{array}{l}\text { Life threatening symptoms like } \\
\text { potentially low cardiac output, } \\
\text { coagulopathy, multiple organ } \\
\text { failure, grade } 4 \text { organ toxicity, } \\
\text { no transaminitis }\end{array}$ & $\begin{array}{l}\text { Mechanical ventilation } \\
\text { Use of immune suppressors }\end{array}$ \\
\hline 5 & Death & - \\
\hline
\end{tabular}

\section{CONCLUSION}

Advances made in immunotherapeutic techniques are quite promising but regular use of such treatment modalities requires appropriate recognition and management of potential hazards associated with them, CRS is one of the emerging complexities associated with immunotherapies. CRS can be presented with mild to life threatening symptoms, therefore it is important for the clinicians to outline the effective management strategy which not only prevents the life threatening symptoms but also avoids the unnecessary immunosuppression which can lead to the decreased efficacy of immunotherapeutic regimens. More intense studies are needed for better understanding of CRS pathophysiology and as the severity and complications of CRS are dependent on burden of disease, use of such 
regimens in patients with lower burden may be produce fruitful outcomes with reduced toxicities.

\section{ACKNOWLEDGEMENT}

None

\section{CONFLICTS OF INTEREST}

The authors declare that there is no conflict of interest.

\section{REFERENCES}

1. Breslin S. Cytokine-Release Syndrome: Overview and Nursing Implications. Clinical Journal of Oncology Nursing, 2006; 11(1 suppl): 37-42.

2. Preeti Sharma, Pradeep Kumar, Rachna Sharma Natural Killar Cells; Their Role in Immuno-surveillance JCDR Accepted, 2017; 11(8): BE01-BE05.

3. Mark Wing. Monoclonal Antibody First Dose Cytokine Release Syndromes-Mechanisms and Prediction, Journal of Immunotoxicology, 2008; 5(1): 11-15.

4. Suntharalingam G, Perry MR, Ward S, Brett SJ, Castello $\mathrm{CA}$, Brunner MD, et al. Cytokine storm in a phase 1 trial of the anti-CD28 monoclonal antibody TGN1412. N. Engl. J. Med., 2006; 355(10): 1018-28.

5. Lee DW, Gardner R, Porter DL, Porter DL, Louis CU, Ahmed $\mathrm{N}$,et al. Current concepts in the diagnosis and management of cytokine release syndrome. Blood, 2014; 124(2): 188-95.

6. Teachey DT, Rheingold SR, Maude SL, Zugmaier G, Barrett DM, Seif AE,et al. Cytokine release syndrome after blinatumomab treatment related to abnormal macrophage activation and ameliorated with cytokinedirected therapy. Blood, 2013; 121(26): 5154-7.

7. Davila ML, Riviere I, Wang X, Bartido S, Park J, Curran $\mathrm{K}$,et al. Efficacy and toxicity management of 19-28z CAR $T$ cell therapy in B cell acute lymphoblastic leukemia. Sci. Trans. Med., 2014; 6(224): 224ra225.

8. Gore L, Zugmaier G, Handgretinger R, Locatelli F, Trippett TM, Rheingold SR,et al. Cytological and molecular remissions with blinatumomab treatment in second or later bone marrow relapse in pediatric acute lymphoblastic leukemia (ALL). J. Clin. Oncol., 2013; 31(suppl 15): 10007.

9. Kochenderfer JN, Dudley ME, Feldman SA, Wilson WH, Spaner DE, Maric l,et al. B-cell depletion and remissions of malignancy along with cytokineassociated toxicity in a clinical trial of anti-CD19 chimeric-antigen-receptortransduced T cells. Blood, 2012; 119(12): 2709-20.

10. Grupp SA, Kalos M, Barrett D, Aplenc R, Porter DL, Rheingold SRet al. Chimeric antigen receptor-modified T cells for acute lymphoid leukemia. N. Engl. J. Med., 2013; 368(16): 1509-18.

11. Brudno JN, Somerville RP, Shi V, Rose JJ, Halverson DC, Flower DH,et al. Allogeneic T cells that express an anti-CD19 chimeric antigen receptor induce remissions of B-cell malignancies that progress after allogeneic hematopoietic stem-cell transplantation without causing graft-versus-host disease. J. Clin. Oncol., 2016;
34(10): 1112-21.

12. Kochenderfer JN, Dudley ME, Kassim SH, Somerville $\mathrm{RP}$, Carpenter RO, Stetler-Stevenson M,et al. Chemotherapy-refractory diffuse large B-cell lymphoma and indolent B-cell malignancies can be effectively treated with autologous T cells expressing an anti-CD19 chimeric antigen receptor. J. Clin. Oncol., 2015; 33(6): 540-9.

13. Porter DL, Hwang WT, Frey NV,Lacey SF, Shaw PA, Loren AW,et al. Chimeric antigen receptor $T$ cells persist and induce sustained remissions in relapsed refractory chronic lymphocytic leukemia. Sci. Transl. Med, 2015; 7(303): 303ra139.

14. Maude SL, Frey N, Shaw PA, Aplenc R, Barrett DM, Bunin NJ, et al. Chimeric antigen receptor $\mathrm{T}$ cells for sustained remissions in leukemia. N. Engl. J. Med., 2014; 371(16): 1507-17.

15. Lee DW, Kochenderfer JN, Stetler-Stevenson M, Cui YK, Delbrook C, Feldman SA, et al. T cells expressing CD19 chimeric antigen receptors for acute lymphoblastic leukaemia in children and young adults: a phase 1 dose-escalation trial. Lancet, 2015; 385(9967): 517-28.

16. Brentjens RJ, Davila ML, Riviere I, Park J, Wang $X$, Cowell LG, et al. CD19-targeted T cells rapidly induce molecular remissions in adults with chemotherapyrefractory acute lymphoblastic leukemia. Sci. Transl. Med., 2013; 5(177): 177ra38.

17. Porter DL, Levine $B L$, Kalos $M$, Bagg $A$, June $C H$. Chimeric antigen receptor-modified T cells in chronic lymphoid leukemia. N. Engl. J. Med., 2011; 365(8): 725-33.

18. Brentjens RJ, Riviure I, Park JH, Davila ML, Wang $X$, Stefanski J, et al. Safety and persistence of adoptively transferred autologous CD19-targeted T cells in patients with relapsed or chemotherapy refractory B-cell leukemias. Blood, 2011; 118(18): 4817-28.

19. Porter $D L$, Levine $B L$, Kalos $M, B a g g ~ A$, June $C H$. Chimeric antigen receptor-modified T cells in chronic lymphoid leukemia. N. Engl. J. Med., 2011; 365(8): 725-33.

20. Beatty GL, Haas AR, Maus MV, Torigian DA, Soulen MC, Plesa G, et al. Mesothelin-specific chimeric antigen receptor $m R N A$-engineered T cells induce antitumor activity in solid malignancies. Cancer Immunol. Res., 2014; 2(2): 112-20.

21. Shimizu M, Nakagishi Y, Kasai K, Yamasaki Y, Miyoshi $\mathrm{M}$, Takei $\mathrm{S}$, et al. Tocilizumab masks the clinical symptoms of systemic juvenile idiopathic arthritisassociated macrophage activation syndrome: the diagnostic significance of interleukin-18 and interleukin-6. Cytokine, 2012; 58(2): 287-94.

22. Levine BL. Performance-enhancing drugs: design and production of redirected chimeric antigen receptor (CAR) T cells. Cancer Gene Therapy, 2015; 22(2): 79-84.

23. Magee MS. Challenges to chimeric antigen receptor (CAR)-T cell therapy for cancer. Discov. Med., 2014; 18(100): 265-71.

24. Amelia M. Huehls, Tiffany A. Coupet, and Charles L. Sentman. Bispecific $T$ cell engagers for cancer immunotherapy. Immunol. cell boil, 2015; 93(3): 290-6. 25. Herrmann I, Baeuerle PA, Friedrich M, Murr A, Filusch 
$S$, Ruttinger D, et al. Highly Efficient Elimination of Colorectal Tumor-Initiating Cells by an EpCAM/CD3Bispecific Antibody Engaging Human T Cells. PLOS ONE. 2010; 5(10): e13474.

26. Frankel SR, Baeuerle PA. Targetting T cells to tumor cells using bispecific antibodies, Curr. Opin. Chem. Biol., 2013; 17(3): 385-92.

27. Arkader R, Troster EJ, Lopes MR,Jתnior RR, Carcillo $\mathrm{JA}$, Leone $\mathrm{C}$,et al. Procalcitonin does discriminate between sepsis and systemic inflammatory response syndrome. Arch. Dis. Child, 2006; 91(2): 117-20.

28. Teachey DT, Lacey SF, Shaw PA, Melenhorst JJ, Maude $\mathrm{SL}$, Frey N, et al. Identification of Predictive Biomarkers for Cytokine Release Syndrome after Chimeric Antigen Receptor T cell Therapy for Acute Lymphoblastic Leukemia. Cancer Discov., 2016; 6(6): 664-679.

29. Turtle CJ, Hanafi LA, Berger C, Gooley TA, Cherian $S$, Hudecek $M$, et al. CD19 CAR-T cells of defined CD4+:CD8+ composition in adult B cell ALL patients. J. Clin. Invest., 2016; 126(6): 2123-38.

30. Heslop HE, Slobod KS, Pule MA, Hale GA, Rousseau A, Smith CA et al. Long-term outcome of EBV-specific T-cell infusions to prevent or treat EBV-related lymphoproliferative disease in transplant recipients. Blood, 2010; 115(5): 925-35.

31. Scholler J, Brady TL, Binder SG, Hwang WT, Plesa G, Hege, KM et al. Decade-long safety and function of retroviral-modified chimeric antigen receptor $\mathrm{T}$ cells. Sci. Transl. Med., 2012; 4(132): 132ra53.

32. Klinger $M$, Brandl $C$, Zugmaier $G$, Hijazi $Y$, Bargou $\mathrm{RC}$, Topp MS, et al. Immunopharmacologic response of patients with Blineage acute lymphoblastic leukemia to continuous infusion of T cell-engaging CD19/CD3bispecific BiTE antibody blinatumomab. Blood, 2012; 119(26): 6226-33.

33. Iyer SS, Cheng G. Role of interleukin 10 transcriptional regulation in inflammation and autoimmune disease. Crit Rev Immunol, 2012; 32(1): 23-63.

34. Shailza Shreshtha, Preeti Sharma, Pradeep Kumar, Rachna Sharma Natural Killar Cells; An insight into their role in pregnancy $J C D R, 2018,12(1): 1-7$

35. Singh JA, Beg S, Lopez-Olivo MA. Tocilizumab for rheumatoid arthritis: a Cochrane systematic review. J. Rheumatol., 2011; 38(1): 10-20.

36. Risma K, Jordan MB. Hemophagocytic lymphohistiocytosis: updates and evolving concepts. Curr. Opin. Pediatr., 2012; 24(1): 9-15

37. Garbers C, Aparicio-Siegmund S, Rose-John S. The IL-6/ gp130/ STAT3 signaling axis: recent advances towards specific inhibition. Curr. Opin. Immunol., 2015; 34(1): 75-82.

38. Horneff $G$, Schmeling $H$, Biedermann $T$, Foeldvari I, Ganser G, Girschick HJ, et al. The German etanercept registry for treatment of juvenile idiopathic arthritis. Ann. Rheum. Dis., 2004; 63(12): 1638-44.

39. Bonifant $\mathrm{CL}$, Jackson HJ, Brentjens RJ, Curran KJ. Toxicity and management in CAR T-cell therapy. Molecular Therapy-Oncolytics, 2016; 3: 16011.

40. Jennifer NB, Kochenderfer JN. Toxicities of chimeric antigen receptor $T$ cells: recognition and management. Blood, 2016; 127(26): 3321-30. 